\title{
A Case Study on Critical Analysis of Tes
}

\author{
Dr Pratibha Jain, Prof. Megha Mehta \\ (Asst Prof.) \& (Asst. Prof.) \\ Sai Sinhgad Business school, Pune-411041
}

\begin{abstract}
The present study remained as an effort to analyse financial strengths, weaknesses, opportunities and threats of TCS for study period of 5 years from 2009 to 2013. Assessment of the long-term financial health is an important task to formulate business strategy for investors and lenders. Financial SWOT is an important step in financial planning and financial decision making. Objectives of study were to analyse Financial SWOT, profitability, liquidity, solvency and asset management situation of the company. The study used accounting, finance and statistics related techniques which were Ratio analysis, Trend analysis, Working capital growth, Operating and financial leverages, EBIT-EPS analysis, Dividend policy analysis and Statistical measures. The study set certain indicators such as capital structure, working capital, profitability, assets management and dividend decision, related to the four facets i.e. strength, weakness, opportunity and threat in terms of financial aspects of TCS. The major findings revealed that the overall financial position of TCS in terms of $F-S W O T$ was quite satisfactory .

Keywords: SWOT,Capital structure,asset management,dividend decision, profitability.
\end{abstract}

\section{Introduction:}

Present age is the age of global competition. In this competitive environment the success or failure of any business organisation depends upon effective use of financial resources. Consideration of non financial activities like analysis of financial strengths, weaknesses, opportunities and threats is also matter of importance. Thus SWOT (Strengths, Weaknesses, Opportunities, Threats) analysis is a good technique for building a strong competitive position for any organisation. The concept of financial SWOT was taken up to analyse the overall trends in operating and financial performances of TCS, by appropriately linking up the relevant aspects of performance. The financial performance includes the trends and the inter-relationships between different aspects of financial management and its overall influence on profitability.

\section{Review Of Literature:}

The present study considered some research work already done by the different scholars and researchers as follows :

Bansal (1984) tried to identify the financial measures of performance in public sector enterprises by constructing 91 different types of ratios. He employed the factor analysis to consider different sets of variables to evaluate the profitability of Public Sector Enterprises.

Randall S. Hansen and Katharine Hansen (1996) found SWOT analysis as a useful technique in career planning also. He suggested that while analysing SWOT one should set a course for career planning, evaluation of current situation, assessment of his own strengths and weaknesses and develop awareness about external opportunities and threats in the set career.

M. Sakthivel Murrugan(2001) studied financial and physical performance of (ONGC) for the period from 1994 to 2000 . The collected data were analysed by using techniques of ratio analysis, trend analysis and "Z" score analysis. He found that liquidity, solvency and profitability of the company was in a better position compared to other public sector undertakings of India.

Ajeet Khurana(2005) considered SWOT analysis as a useful technique to analyse a company particularly in order to evaluate business plans, performance and outlook and to make stock investment decisions. He has suggested a checklist of 15 points each for strength, weakness, opportunity and threat for the purpose of financial analysis.

Amit Singh Sisodiya and SailajaMannavar (2006)explained acquisition of Balsara group by Dabur India Ltd. Balsara's focus was not right and they were not deploying their resources in the right manner thus over the last two financial years, Balsara had only accumulated losses. As a result, in Jan. 2005 Dabur acquired Balsara and earned net profit of Rs. 7.3 crores because of strong financial practices.

Mistry(2011) explained capital employed and net operating profit after tax have positive impact on next period's profit while return on assets has negative impact thereon. 


\section{NEED AND OBJECTIVES OF THE STUDY}

The study will be very useful not only to the corporate bodies but also to the parties related including regulatory bodies, investors, academicians, planners, researchers etc. Thus the following were the main objectives of the present research work.

1. To understand and analyse the external and internal financial strengths, weaknesses, opportunities and threats related with TCS during the study period.

2. To evaluate the liquidity, solvency and profitability position of TCS.

3. To analyse asset management situation and Dividend assessment of TCS.

\section{Research Methodology}

Methods of Data collection: -For collecting secondary data, annual reports of companies will be used as well as financial reports available on various stock market websites are also used. No field work has been done in order to collect primary data for the study and the study is entirely descriptive and analytical. The secondary data, figure, facts and information has been collected from various publications, trade publications, brochures, standard textbooks, internet journals, articles etc.

Data Analysis \& Interpretation: - Collected data is analysed and interpreted with the help of accounting and statistical tools and techniques which are as follows-

1. Ratio analysis

2. Average

3. Trend analysis

4. Leverage analysis

Time Period of the Study:-The study has been conducted from 2009 to 2013 ie. for 5 years.

(i) Capital structure analysis

IV. Data Analysis \& Interpretation

Table 1 : Capital Structure (2009-2013)

\begin{tabular}{|c|c|c|c|c|c|c|}
\hline Particulars & 2009 & 2010 & 2011 & 2012 & 2013 & Average \\
\hline Debt-equity ratio & 0.01 & 0.01 & 0.01 & 0.01 & 0.01 & 0.01 \\
\hline $\begin{array}{l}\text { Total Debt to owners } \\
\text { fund }\end{array}$ & 0.01 & 0.01 & 0.01 & 0.01 & 0.01 & 0.01 \\
\hline Interest coverage & 784.41 & 674.43 & 435.25 & 841.63 & 513.84 & 649.91 \\
\hline $\begin{array}{l}\text { Fin. Charges coverage } \\
\text { ratio }\end{array}$ & 840.52 & 723.63 & 462.68 & 857.98 & 540.06 & 684.97 \\
\hline \multicolumn{7}{|l|}{ B. Leverage } \\
\hline DOL & 0.87 & 0.81 & 0.95 & 0.97 & 1.08 & 0.94 \\
\hline DFL & 1.00 & 1.00 & 1.00 & 1.00 & 1.00 & 1.00 \\
\hline DCL & 0.87 & 0.81 & 0.95 & 0.97 & 1.08 & 0.94 \\
\hline Long-term debt & 100 & 128.23 & 268.95 & 220.43 & 411.56 & 225.83 \\
\hline Res. and surplus & 100 & 88.53 & 101.86 & 238.37 & 404.06 & 186.56 \\
\hline Interest & 100 & 111.87 & 145.56 & 185.39 & 243.55 & 157.27 \\
\hline Debt-equity ratio & 100 & 100 & 100 & 100 & 100 & 100 \\
\hline
\end{tabular}

Debt equity ratio remained constant ie. 0.01 throughout the whole study period. The ratio was below the norm of 1:1. A low ratio of debt to equity implied a greater claim of owners than that of creditors. There was financial opportunity to increase loans and borrowings for operational flexibility. Total debt to owner's fund ratio again remained constant ie. 0.01 throughout the whole study period. As such the rule of thumb suggests a ratio of $0.67: 1$. It indicated financial opportunity in capital structure to increase proportion of permanent capital consisting long-term debt.

Interest coverage was highest 841.63 times for 2012-13 while lowest 435.25 times for 2011-12. The average ratio was around 649.91 times. The ratio was very high from standard of 8 times for study period reflected that a company has an undesirable lack of debt or is paying down too much debt with earnings that could be used for other projects. Financial expenses ratio remained high during the study period having average 684.97 times. The ratio was highest during 2012-2013 i.e. 857.98 times while the lowest 462.68 times during 2011-12. 
The DOL, more than 1 is always favourable indicating financial strength. The DOL remained less than 1 in four years of the study period but the trend was fluctuating which was not good for speedy growth. The company faced threats of highly technology based industry. The degree of financial leverage indicated correlation between PBIT and EPS. The DFL was constant throughout the study period with average of 1.00.The degree of combined leverage remained below one except during 2013-14. The average DCL was around 0.94 indicated that one percent change in sales could change one percent in TCS's EPS. The DOL and DFL were combined to see the effect of total leverage on EPS associated with a given change in sales.

The trend values of long-term debt was $128.23 \%$ in $2010-1011$ while $411.56 \%$ in $2013-14$, reflected financial threat towards long-term solvency position as shown in Table 4.1. Reserves and surplus increased to $404.06 \%$ during 2013-14, thus following increasing trend. Interest increased from $111.87 \%$ in $2010-11$ to $243.55 \%$ in 2013-14. Increasing trend of interest was not good for company because, it had increased financial liability of the company.

(ii) Working capital analysis

Table 2: Working Capital (2009-2013)

\begin{tabular}{|c|c|c|c|c|c|c|}
\hline Particulars & 2009 & 2010 & 2011 & 2012 & 2013 & Average \\
\hline \multicolumn{7}{|c|}{$\begin{array}{l}\text { A. Working capital ratios } \\
\text { (in times) }\end{array}$} \\
\hline Current ratio & 1.83 & 1.49 & 2.45 & 2.48 & 2.85 & 2.22 \\
\hline Quick ratio & 1.83 & 1.48 & 2.44 & 2.47 & 2.88 & 2.22 \\
\hline $\begin{array}{l}\text { Inventory } \\
\text { turnover }\end{array}$ & 1321.77 & 3398.94 & 5451.71 & 9386.18 & 7638.32 & 5439.38 \\
\hline Debtors turnover & 6.00 & 6.54 & 7.19 & 5.59 & 4.77 & 6.02 \\
\hline \multicolumn{7}{|c|}{ B. Trend measure (in percentage) } \\
\hline Working capital & 100 & 84.78 & 215.84 & 321.09 & 465.47 & 237.44 \\
\hline
\end{tabular}

Table 2 depicts that the current ratio remained satisfactory with certain exceptions during the study period. The ratio remained highest in 2013-14, being 2.85 times while the lowest in 2010-11, which was 1.49 times. The ratio indicated financial strength of overall good working capital management and good paying capacity to the short-term obligations. The average remained at 2.22 times.

The quick ratio varied from 1.48 times to 2.88 times with the average of 2.22 times. The ratio remained more than 1 for whole study period which indicated that the company was paying its cash obligations in an efficient way and had financials strength of good cash management and receivables management.

The inventory turnover ratio was highest 9386.18 times during 2012-13 while lowest 1321.77 times during 2009-10. The average ratio remained 5439.384 times. The turnover rate of stock was very high reflected financial threat of inefficient management of stock.

Debtors turnover ratio has shown financial strength of adequate and strong trade credit management of the company. It remained highest 7.19 times during 2011-12 while lowest 4.77 times during 2013-14.

The trend of working capital shown in Table 2 was increasing. The working capital was $84.78 \%$ during 2010 2011 then increased upto $465.47 \%$ in 2013-2014 reflected financial strength of efficient management of liquid sources.

(iii) Profitability analysis:

Table 3: Profitability(2009-2013)

\begin{tabular}{|c|c|c|c|c|c|c|}
\hline Particulars & 2009 & 2010 & 2011 & 2012 & 2013 & Average \\
\hline \multicolumn{7}{|c|}{ A. Profitability ratios (in percentage) } \\
\hline Gross profit margin & 25.01 & 26.89 & 28.12 & 27.52 & 27.88 & 27.084 \\
\hline Net profit ratio & 20.74 & 24.13 & 25.42 & 26.42 & 25.24 & 24.39 \\
\hline
\end{tabular}


A Case Study On Critical Analysis Of Tcs

\begin{tabular}{|l|r|r|r|r|r|r|}
\hline Operating profit ratio & 26.87 & 28.93 & 29.96 & 29.30 & 29.54 & 28.92 \\
\hline Return On Capital Employed & 48.07 & 55.31 & 44.38 & 42.46 & 43.27 & 46.70 \\
\hline Return on Assets & \multicolumn{7}{|l|}{165.86} & 126.49 & 99.53 & 76.72 & 136.38 & 121.00 \\
\hline B. EBIT-EPS analysis & & & & & \\
\hline EBIT (Rs. crores) & 5564.59 & 6849.27 & 9258.26 & 14070.90 & 16536.66 & 10455.94 \\
\hline EPS (Rs.) & 47.92 & 28.62 & 38.62 & 55.97 & 65.23 & 47.272 \\
\hline C. Trend measures (in percentage) & & & & & \\
\hline Sales & 100 & 102.86 & 130.67 & 173.45 & 216.15 & 144.63 \\
\hline PBIT & 100 & 123.09 & 166.38 & 252.86 & 297.18 & 187.90 \\
\hline PAT & 100 & 119.64 & 161.19 & 233.72 & 272.27 & 177.36 \\
\hline EPS & 100 & 59.72 & 80.59 & 116.80 & 136.12 & 98.65 \\
\hline
\end{tabular}

Gross profit margin of the company was satisfactory, remained 25.01\% during 2009-10 while $27.88 \%$ during 2013-14. A satisfactory ratio of gross profits to sales clearly reflected financial strength showing good management and low cost of production .

The operating profit ratio remained highest, $29.96 \%$ during 2011-12 while lowest, $26.87 \%$ during 2009-10 with the average of $28.92 \%$. The net profit ratio was highest, $26.42 \%$ in $2012-13$ and lowest, $20.74 \%$ during 2009-10. It indicated that the management of the company was able to operate the business with sufficient success and recover expenses from revenues of the period.

Return on assets was highest $165.86 \%$ during $2009-10$ and lowest $76.72 \%$ in $2012-13$ revealed financial strength of satisfactory position. The average ratio was around $121.00 \%$. Return on assets of $10 \%$ is considered favourable for any firm. The ratio was very high from standard .

Return on capital employed remained highest i.e. 55.31\% during 2010-11 while lowest $42.46 \%$ during 2012-13. The average was $46.70 \%$ indicated good return on capital employed.

EBIT-EPS analysis of TCS was used in the direction of designing a firm's optimal capital structure. EBIT of the company was in increasing order having highest value Rs. 16536.66 crores during 2013-14 while lowest Rs. 5564.59 crores during 2009-10. EPS had fluctuating trend varied from Rs. 47.92 during 2009-10 to Rs. 65.23 during 2013-14. Increasing EBIT and EPS were satisfactory and good signal for the company Table 3 reveals that sales, PBIT, PAT and EPS had increasing trend reflected financial strength of growth and profitability. They increased to $216.15 \%, 297.18 \%, 272.27 \%, 136.12 \%$ respectively in $2013-14$.

(iv) Analysis of assets management

Table 4: Assets Management

\begin{tabular}{|c|c|c|c|c|c|c|}
\hline Particulars & 2009 & 2010 & 2011 & 2012 & 2013 & Average \\
\hline \multicolumn{7}{|c|}{ A. Assets management ratios (in times) } \\
\hline FA turnover & 5.15 & 4.74 & 4.91 & 5.39 & 5.32 & 5.10 \\
\hline TA turnover & 1.66 & 1.52 & 1.50 & 1.56 & 1.48 & 1.54 \\
\hline \multicolumn{7}{|c|}{ B. Trend measure (in percentage) } \\
\hline Total Assets & 100 & 112.35 & 145.48 & 185.02 & 242.65 & 157.10 \\
\hline
\end{tabular}

The adequacy of assets, more importantly fixed assets in a business affected profits. The fixed assets turnover ratio remained 4.74 to 5.39 times which was almost satisfactory as compared to standard accepted of 5 times. The ratio remained 5.10 times as an average that indicated good investments in fixed assets compared to sales.

Total assets turnover ratio shown a mixed trend of increase and decrease. However if the extremes were considered, it shown a good improvement on the part of the organisation. The ratio has started at 1.66 times in 2009-10. After decline and increase, it has reached 1.56 times in 2012-13. Average was 1.54 times. Ratio below standard of 2 times indicated less frequency with which the assets were realized.

The trend of total assets given in Table 4 increased to $242.65 \%$ in 2013-14 reflected financial strength of efficient utilisation of both fixed and current assets. 
(v) Dividend Decision Analysis:

Table 5 : Dividend Decision

\begin{tabular}{|c|c|c|c|c|c|c|}
\hline Particulars & 2009 & 2010 & 2011 & 2012 & 2013 & Average \\
\hline \multicolumn{7}{|c|}{ A. Dividend decision ratios } \\
\hline $\begin{array}{l}\text { Dividend coverage } \\
\text { (times) }\end{array}$ & $\begin{array}{r}2.9 \\
7 \\
\end{array}$ & 2.24 & 2.76 & 1.43 & 3.42 & 2.56 \\
\hline Dividend payout (\%) & 34.20 & 81.61 & 42.21 & 51.94 & 39.30 & 49.85 \\
\hline \multicolumn{7}{|c|}{ B. Trend measures (in percentage) } \\
\hline Book value per share & 100 & 56.25 & 72.98 & 92.75 & 121.62 & 88.72 \\
\hline
\end{tabular}

\begin{tabular}{|l|r|r|r|r|r|r|}
\hline $\begin{array}{l}\text { Dividend per ordinary } \\
\text { share }\end{array}$ & 100 & 142.86 & 100 & 178.57 & 157.14 & \\
\hline Dividend payout & 100 & 238.63 & 123.42 & 151.87 & 114.91 & 135.71 \\
\hline
\end{tabular}

Dividend coverage ratio was having fluctuating trend .The ratio measured the ability of company to pay dividend on shares at a stated rate of return. The ratio remained highest 3.42 times during 2013-14 and lowest 1.43 times during 2012-13. The average ratio was around 2.56 times and the increasing trend during last year indicated simultaneous increase in net profits (PAT) and dividend amount.

Dividend payout ratio registered a fluctuating trend, remained highest $81.61 \%$ during $2010-11$ while lowest $34.20 \%$ during $2009-10$ with the average payout of $49.85 \%$. The company was distributing almost $50 \%$ of the profits as dividends showing financial strength.

Table 5 reveals that the trend of book value per share fluctuated and became $121.62 \%$ in 2013 14.Book value per share was not stable but in 2013-14, the value was highest has shown financial opportunity for improving the profitability policy. Dividend per ordinary share had increasing trend except in 2011-12. Dividend payout ratio was $238.63 \%$ in $2010-11$ while $123.42 \%$ in $2011-12$ then finally $114.91 \%$ in $2013-14$. Fluctuating trend of D/P ratio indicated financial threat of liberal dividend policy and company was not giving fixed dividends but on the basis of profits of the current year.

\section{Observations And Findings}

Important observations and findings of the study covering different constituents of F-SWOT i.e. financial strengths, weaknesses, opportunities and threats of TCS are given below. The average of five years $\left(\mathrm{Av}_{5}\right)$ was used most of the times for analysis in the study.

Financial strengths :The satisfactory current ratio $\left(\mathrm{Av}_{5}: 2.22\right.$ times) and quick ratio $\left(\mathrm{Av}_{5}: 2.22\right.$ times) reflected good working capital management and liquidity position. Satisfactory gross profit margin $\left(\mathrm{Av}_{5}: 27.084 \%\right)$, Net Profit Margin $\left(\mathrm{Av}_{5}: 24.39 \%\right)$ \&Operating Profit Ratio $\left(\mathrm{Av}_{5}: 28.92 \%\right)$ revealed cost price effectiveness of the operations. Debtors turnover $\left(\mathrm{Av}_{5}: 6.02\right.$ times) of the company reflected strong trade credit management. Good ROA $\left(\mathrm{Av}_{5}: 121.00\right.$ times )depicted high returns on assets. Fixed Assets turnover ratio $\left(\mathrm{Av}_{5}: 5.10\right.$ times) indicated efficient management $\&$ utilisation of fixed assets. Dividend Payout ratio $\left(\mathrm{Av}_{5}\right.$ $: 49.85 \%$ )revealed financial strength because the firm retained $50 \%$ of the profits for future investment \& growth. combined leverage $\left(\mathrm{Av}_{5}: 0.94\right)$ analysis reflected that TCS was not a risky company.

Financial weaknesses : Total assets turnover $\operatorname{ratio}\left(\mathrm{Av}_{5}: 1.54\right.$ times) shows less frequency with which the assets were realized .Dividend coverage ratio $\left(\mathrm{Av}_{5}: 2.56\right.$ times) was low showing inability of company to pay dividends on shares

Financial opportunities : Financial opportunity for better debt equity mix was shown by debtequity $\left(\mathrm{Av}_{5}: 0.01\right.$ times) and Total debt to owner's fund ( $\mathrm{Av}_{5}: 0.01$ times) ratios. Increasing ROCE in 2010$11(55.31 \%)$ shown opportunity to increase productivity of long term funds. EBIT_EPS analysis revealed the direction of designing optimal capital structure. Degree of operating leverage $\left(\mathrm{Av}_{5}: 0.94\right)$ reflected abundant financial opportunities for tackling operating expenses of the TCS.

Financial threats : There was financial threat of high interest coverage ratio $\left(\mathrm{Av}_{5}: 649.91\right)$ and financial charges coverage ratio $\left(\mathrm{Av}_{5}: 684.97\right)$ shown inability to pay fixed charges. Inventory Turnover ratio was very high reflected threat of inefficient manangement of inventory $\left(\mathrm{Av}_{5}: 5439.384\right.$ times) decreasing gross profit margin in 2012-13. 


\section{Conclusion}

On the basis of analysis of capital structure ratios, the solvency position of these corporations as a whole could not be called sound. Moreover the policy of employing more borrowed funds as compared to own funds could not be justified as financial expenses reduced the profits. The current and quick ratio calculated have shown that the liquidity position was sound for these organisations .Trends of sales, PBIT, PAT and EPS justified financial strength of satisfactory profitability.Thus the overall profitability of TCS measured with the help of different ratios can be said to be satisfactory ,they had financial opportunity to earn maximum or optimum profits for economic prosperity. total assets turnover was very poor \& on the contrary Fixed Assets turnover revealed financial strength of sufficient assets held by the company. After conclusion of capital structure, profitability, working capital, assets management and dividend decision, sustainable growth rate reflected financial SWOT in an effective manner. The average growth rate of TCS indicated financial opportunity of better debt equity mix and dividend payout.

\section{References}

[1]. Bansal S.C.; "Financial Measures of Performance in Public Enterprises", Indian Journal of Commerce, Lucknow, Vol. 141, No. 4, December, 1984, pp. 107-130.

[2]. Hansen Randall S. and Hansen Katherine; "Using a SWOT Analysis in Your Career Planning”, Published by Quint Es sential Careers, Deland, Florida, 1996, pp. 1-4.

[3]. BhattacherjeeSamata; "SWOT Analysis for Babhanan Sugar Mills Ltd.", Strategic Management : Indian Experience, Gyan Publishing House, New Delhi, 1997, pp. 267-276.

[4]. Murugan M. Sakthivel; "Performance Evaluation of ONGC - A Case Study", Indian Journal of Public Enterprise, Institute of Public Enterprise Research, Allahabad, Vol. 17, No. 31, Dec. 2001, pp. 83-91.

[5]. KhuranaAjeet; "Understanding and Using SWOT Analysis", from businessmajors.about.com, About, Inc., New York Time Co., 2005, pp 1-5.

[6]. Sisodiya Amit Singh and MannavarSailaja; "Balsara'sTurnaround :Dabur Delivers", Chartered Financial Analyst, The ICFAI University Press, Hyderabad, Jan., 2006, pp. 62-65.

[7]. Gupta Santosh; "Research Methodology and Statistical Techniques", Deep \& Deep Publications, New Delhi, 2001, p. 105.

[8]. Kishore Ravi M.; "Management Accounting", Taxmann Allied Services Pvt. Ltd., New Delhi, 2000, p. 26.

[9]. Khan M.Y. and Jain P.K.; "Theory and Problems in Financial Management", Tata McGraw-Hill Publishing Company Ltd., New Delhi, 2000, p 9.1.

\section{JOURNALS \& PUBLICATIONS}

[10]. Accounting Research, ICFAI University, Hyderabad.

[11]. Applied Finance, The ICFAI University. The Institute of Chartered Financial Journal Analysis of India, Hyderabad.

[12]. Finance India, Indian Institute of Finance, Ashok Vihar-II, Delhi.

[13]. Indian Journal of Accounting, Journal of Indian Accounting Association, Published from Ujjain.

[14]. NSE News, National Stock Exchange of India Ltd. Mumbai.

\section{INTERNET SITES}

[15]. www. indiapublicsector.com

[16]. www.moneycontrol.com

[17]. ww.google.com

[18]. www.investopedia.com 